\title{
Acceptance of Fashion Forecast as Reflected in the Street Fashion in Korea
}

\author{
Haekyung $\mathbf{Y u}^{\dagger}$ \\ Dept. of Fashion \& Industry, University of Incheon \\ 스트리트패션에 나타난 한국 소비자들의 패션예즉 수용 \\ 유 혜 경 \\ 인천대학교 패션산업학과 \\ (2007. 4. 9. 접수)
}

\begin{abstract}
Forecasting is a critical task for fashion companies because of continuous change in fashion and long process lead-time. Therefore, it is of great importance for both scholars and companies to understand how forecasted fashion styles are accepted by consumers. This research aimed to investigate consumer acceptance of fashion styles in Korea. The study examined and compared oversea collections of women's wear to the street fashion in Korea for seven seasons from $02 \mathrm{~s} / \mathrm{s}$ to $05 \mathrm{~s} / \mathrm{s}$. Information on oversea collections were obtained from the magazine, Fashion Show, and the street fashion information from Seoul Fashion Design Center. The results showed that overall trends presented in oversea collections have been well accepted, while acceptance of specific styles or items varied. During the period of this research, sporty style and feminine style were very strong in the street fashion. Many styles and items were modified and selectively accepted probably because of cultural differences and limitations of mass production. Some styles which were presented in oversea collections were not accepted in Korea, and at the same time some cases were observed only in the street fashion in Korea. The results of this study provide guidelines for Korean apparel companies in merchandise planning and empirical findings to deepen the understanding on Korean society with respect to fashion.
\end{abstract}

Key words: Fashion acceptance, Fashion forecast, Street fashion, Korean fashion, Fashion collection; 유행수용, 유행예측, 스트리트패션, 한국 패션, 패션 콜렉션

\section{Introduction}

Most apparel companies plan their merchandises long before the merchandises are delivered to retail stores, and thus the companies have to predict which styles would be popular in coming seasons. Forecasting is particularly challenging in apparel industry

${ }^{\dagger}$ Corresponding author

E-mail: yuhkyung@incheon.ac.kr

This work was supported by University of Incheon

Research Grant in 2003. because of highly volatile demand and long process lead-time(Brannon, 2005).

Forecasting in fashion industry takes places in several stages from color and general trend forecast, textile forecast and finally fashion collections by leading designers(Burns \& Bryant, 1997). Naturally, not all forecasted styles are accepted by consumers, and new style becomes a part of fashion only when the styles are accepted by large number of consumers. And consumer acceptance in fashion process is as important as, if not more, fashion innovation and 
forecast. Many factors including culture influence consumer acceptance, and thus, it would be of great value to examine which styles among those forecasted in overseas are well accepted in Korea and infer unique characteristics of Korean fashion market in order to deepen our understanding on Korean society with respect to fashion. From marketing point of view, understanding of consumer acceptance is also critical since almost all Korean apparel companies use styles presented in oversea collections as their references in merchandise planning.

In spite of great importance of consumer acceptance in both academia and fashion industries, relatively few researchers dealt with the topic compared to fashion innovation or fashion leadership(Behling, 1992). Furthermore, most of the previous studies which aimed to examine fashion acceptance in Korea compared designer collections or fashion forecast information by trend forecasting service firms and those studies lacked in providing valid insights on consumer acceptance.

Therefore, the main purposes of this study were to investigate consumer acceptance of fashion in Korea and provide useful guidelines to apparel companies for their merchandise planning. The research compared women's fashion styles presented in oversea collections to the street fashion in Korea for seven seasons from the $2002 \mathrm{~s} / \mathrm{s}$ to $2005 \mathrm{~s} / \mathrm{s}$. Data for oversea collections were obtained from a magazine, Fashion Show and street fashion data collected by the Seoul Fashion Design Center were used for this study. Street fashion data shows what is actually worn by consumers, and in recent years increasing number of studies have used street fashion data in examining various topics including men's fashion style(Kim, 2003), aesthetic styles(Ha, 2005) or cultural characteristics(Cameron, 2000).

The results of this study, even though exploratory in nature, will further our understanding on consumer acceptance of fashion styles, especially the characteristics of consumers acceptance in Korea. The study will also provide guidelines to Korean apparel companies in screening fashion styles and items forecasted in oversea collections for their merchandise planning.

\section{Research Background}

\section{Fashion Forecasting}

Forecasting is a formidable task, and both quantitative and qualitative methods have been developed in many areas to obtain more accurate forecasts. Informations on fashion forecast are made in three stages(Burns \& Bryant, 1997). The first stage is color and trend forecast which are made usually one to two year before corresponding season. Then in textile fairs such as Premiere Vision, leading textile companies show their product samples that they "forecast" will be popular in future, usually one year later. Shortly after the textile fairs, fashion collections by famous designers and apparel companies are held in major fashion centers of the world including Paris, Milan, London and New York. These world class designers and apparel companies are often sources of innovation in global fashion market. Thanks to advances in telecommunication technology, the collections in those fashion centers are broadcasted and watched instantaneously by millions of people around the world. The creations of high fashion designers are presented in the collections six to nine months in advance of corresponding seasons and they are considered as forecast of fashion styles.

Korean apparel companies use several sources of information in merchandise planning. They can obtain forecast informations from both international and domestic fashion forecasting service firms such as IF network. In addition, textile fair is also a good source of information since they often provide fashion forecasts along with textile and prints However, among all the information sources, it is known that Korean apparel companies rely most heavily on information about oversea collections(Lee, 2001). Therefore, it will be very helpful for apparel companies if they can have better grasp of which, among the styles presented in oversea collections, are more likely to be accepted by their customers.

\section{Consumer Acceptance of Fashion}

As noted earlier, consumer acceptance is an impor- 
tant part of fashion diffusion, and a style becomes a fashion style only when the style is accepted by large number of consumers. Nonetheless, there has been a significant lack of empirical studies on fashion acceptance. Behling(1992) noted that most studies on fashion theory focused on fashion leadership and fashion innovation, and previous studies on fashion acceptance often examined the relationship between level of fashion adoption and the individual characteristics(Forsythe et al., 1991). Kim(2001) investigated fashion acceptance and fashion leadership of Korean women, and found that there was positive relationship between fashion leadership and acceptance. Shin(2001) also found that consumers of higher fashion leadership preferred new style.

There were some studies which aimed to examine consumer acceptance at aggregate level. Lee(2001) compared articles on newspapers to the fashion trend forecast by fashion service firms, whereas Park(2000) compared fashion collections held in overseas to the domestic collections. Both Lee(2001) and Park(2000) aimed to examine consumer acceptance in Korea, but the data used in their studies, either newspaper articles or domestic collections, may not reflect real consumer acceptance.

Lee(2003) compared the street fashion to the fashion themes forecasted by a Korean fashion forecasting service firm for 02-03 $\mathrm{f} / \mathrm{w}$. The results showed that among four themes suggested by the firm, $39.04 \%$ of the styles observed in the street fashion data fell into one theme, suggesting that consumer acceptance in Korean market tends to be concentrated around a limited themes.

In summary, there has been a lack of studies on consumer acceptance in spite of its importance. Furthermore, very few studies used empirical data which reflect actual consumer acceptance. In addition, it would be reasonable and helpful to examine how the styles presented in oversea collections are accepted by consumers, since Korean apparel companies use the oversea collection information most widely.

\section{Research Methods}

In this research, oversea fashion collections were operationalized as fashion forecasts since the fashion collections are held in almost one year advance of season, and they are used as "forecasts" by Korean apparel companies. And data for oversea collections were obtained from a magazine, Fashion Show, for seven seasons from $02 \mathrm{~s} / \mathrm{s}$ to $05 \mathrm{~s} / \mathrm{s}$. The magazine was selected for the study because it covers the collections held in all four major fashion cities - Paris, Milan, London and New York and it is most widely circulated magazine of its kind in Korea. Collecting data from other fashion magazines deemed unnecessary because only limited pictures of collections are provided by high fashion designers and companies for press release, and thus consulting another magazine does not increase sample size, but poses high possibility of double counting.

For each season, Fashion Show reports major trends by categories such as office wear, coat, night life and so on. In this research, the collection styles in formal wear category were not analyzed since formal wears are rarely observed on streets. In addition, only women's wear were considered because of large volume of data from both sources.

In order to examine consumer acceptance of forecasted fashion styles, the research used the street fashion data reported by Seoul Fashion Design Center. SFDC collected pictures of street fashion in Seoul by month over the period of this research and offers the street fashion data for free through their internet home page. In this research, S/S season includes March through August, and F/W September till February. Therefore, street fashion data used in this study included data from March 2002 to August 2005. Street fashion data by SFDC were large enough so that street fashion data from other sources were not included in order to increase data consistency.

Pictures of men's fashion, hand bags and shoes were excluded from the SFDC data for this study. The pictures of street fashion are taken in natural settings and very often showed mixed influences of fashion style, individual preferences and taste, and other factors such as weather as Lee(2003) noted. Therefore, only those outfits of which style could be identified were included as in the study by Lee(2003). A total of 1381 street fashion pictures were used in 
the final analysis.

Content analysis was performed to compare the styles shown in the collections to the street fashion. It was not possible to quantify similarities or dissimilarities between the fashion collection and the street fashion data due to qualitative nature of both data. Instead, the styles and items were grouped into four categories, high acceptance, partial acceptance, low acceptance and styles unique in Korean street fashion. The cases were considered "high acceptance", when styles or items in street fashion were almost identical to those presented in fashion collections. "Partial acceptance" included the styles or items in the street fashion which had some elements of design such as material, color, or silhouette that were also found in the oversea fashion collection data. "Low acceptance" included the styles or items found only in the oversea fashion collection data, whereas "styles unique in Korean street fashion" were found only in the street fashion data.

In order to reduce subjectivity of researchers and ascertain high reliability, two researchers together compared all the fashion collection and the street fashion data for each season. There was little difficulty in analyzing the data, and agreement was reached through discussion when the differences in opinions between the researchers were encountered.

\section{Results and Discussion}

\section{Styles of High Acceptance}

$<$ Table 1 $>$ shows which styles among those presented in the oversea collections were highly accepted in Korean fashion market. Short jacket and tightly fitted top were frequently shown in the street fashion as well as in oversea collections. Short jackets and short blouson were very often observed in the

Table 1. Styles of high acceptance

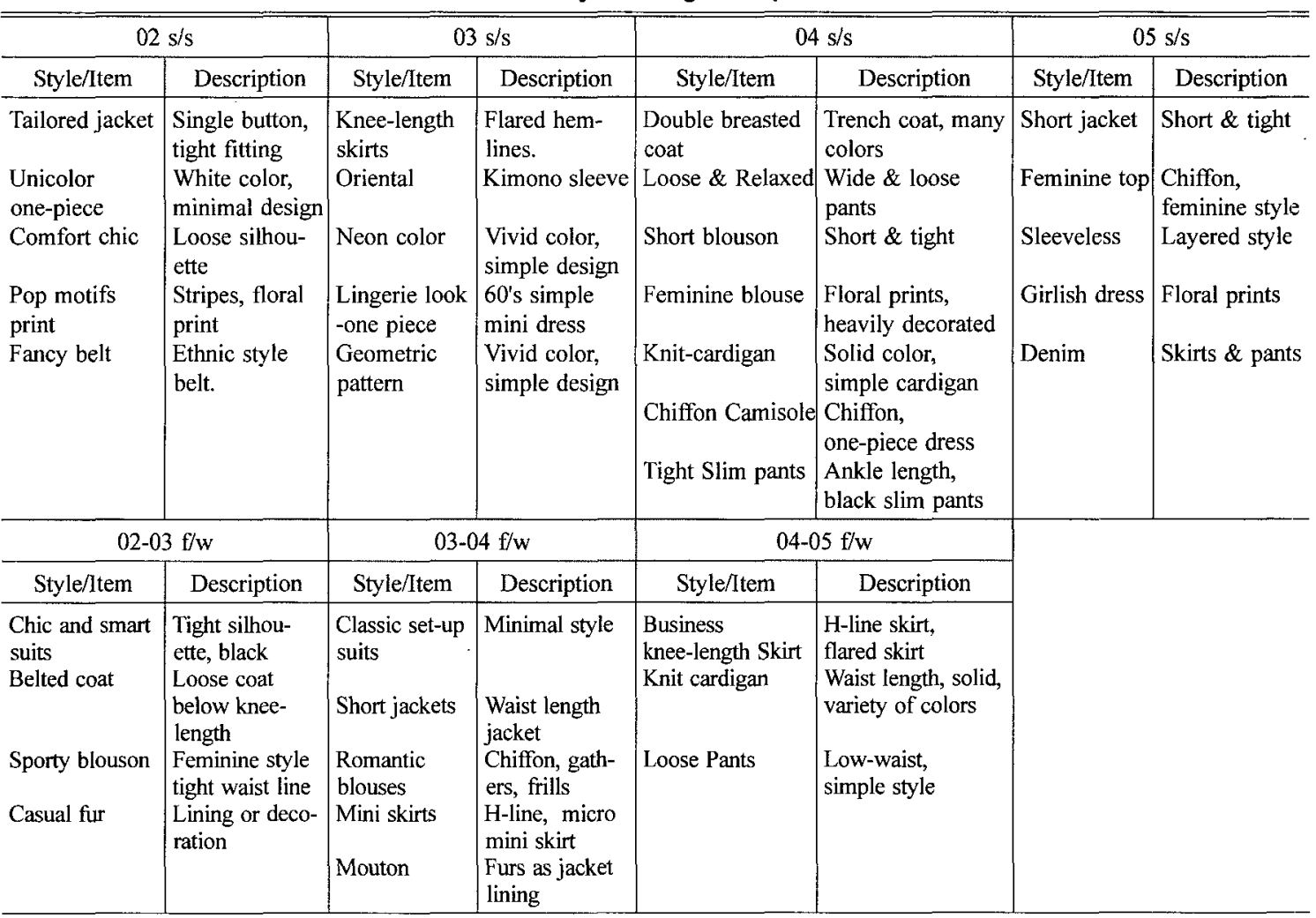


street fashion during the 03-04 f/w, $04 \mathrm{~s} / \mathrm{s}$, and $05 \mathrm{~s} / \mathrm{s}$. In overall, minimal style was dominant in the street fashion with short and tight tops from $02 \mathrm{~s} / \mathrm{s}$ to $05 \mathrm{~s} / \mathrm{s}$.

Feminine style was another trend well accepted in Korean street fashion during the period from $02 \mathrm{~s} / \mathrm{s}$ to $05 \mathrm{~s} / \mathrm{s}$. Frills and gathers, chiffon, and floral prints were frequently observed in the street fashion as in oversea collections, and they all constituted feminine style.

In terms of prints, floral prints among all other prints presented in the overseas collections appeared most frequently in the street fashion. In addition, stripes was also well received in $02 \mathrm{~s} / \mathrm{s}$. But in overall, solid colors appeared much stronger than prints.

Knee length or short skirts were well received in Korea compared to longer skirts. This result may stem from the fact that Koreans are not, on average, as tall as people in western countries.

Certain items were highly accepted in Korea. Simple cardigans of solid colors were highly accepted during $04 \mathrm{~s} / \mathrm{s}$ and the following 04-05 f/w seasons.
This item was very versatile and worn with many items of minimal style. And during those seasons, wide pants were frequently observed in the street fashion. Beginning from $02-03 \mathrm{f} / \mathrm{w}$, furs, both real and fake, were often used as linings in fall/winter items in the street fashion.

\section{Styles of Partial Acceptance}

Even though many styles presented in oversea collections were well accepted in Korea as shown in $<$ Table 1>, more frequently modification of the styles presented in oversea collections were made or only selected designs were accepted in Korean market(Table 2). How each style or item is modified and which style is selectively accepted varied by each case, but there are some common characteristics underlying the styles of partial acceptance. Most of all, while the oversea collections tend to present diverse styles changing every season, in street fashion the styles were modified and accepted in a way to strengthen the main trends. For instance, sporty and

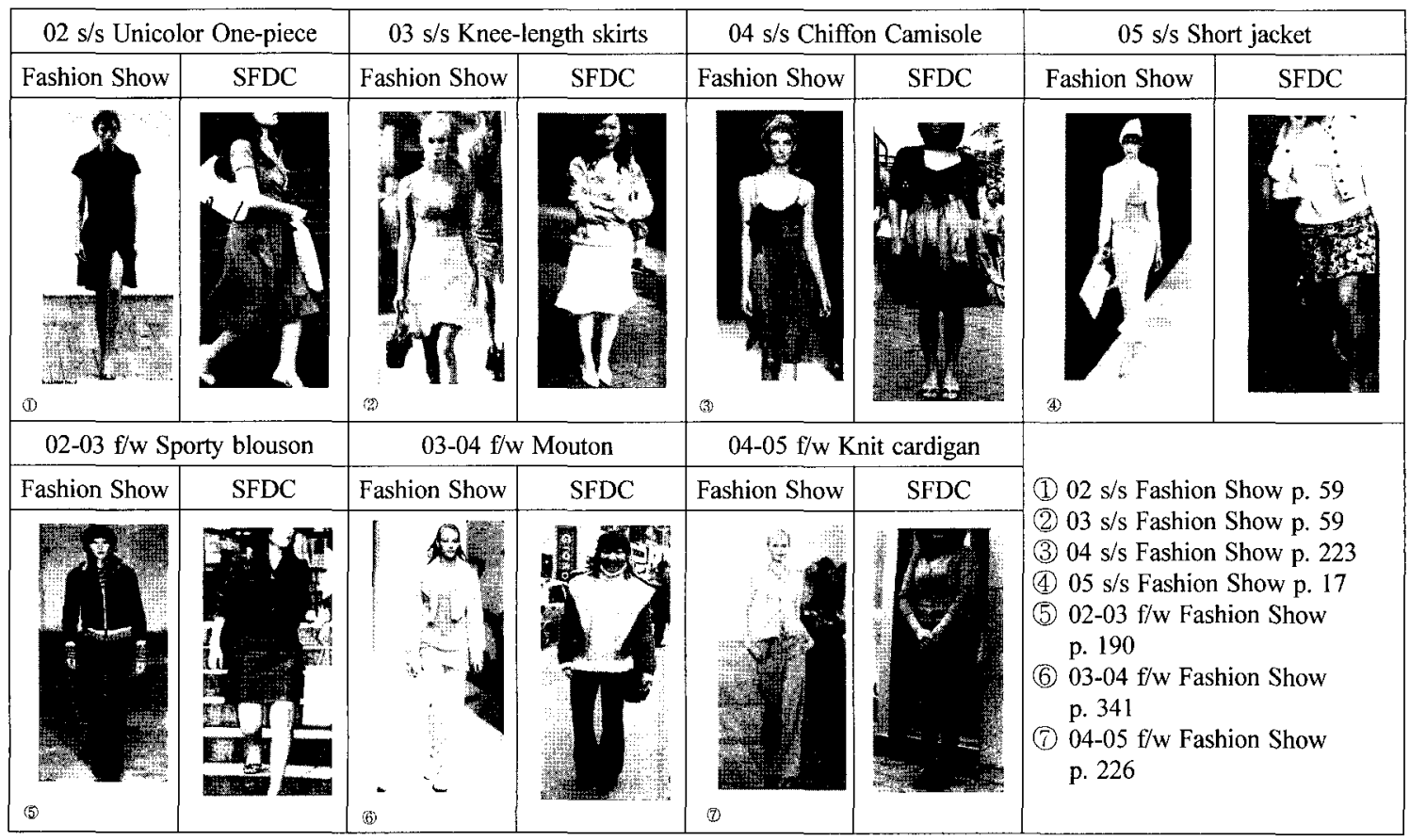

Fig. 1. Examples of high acceptance styles. 
feminine styles were most popular during the period of this study, and all details, materials, and prints were accepted or modified to be consistent with the styles. For example, frills and gathers, chiffon and satin, floral prints were widely accepted, enhancing feminine styles, among all other details, materials, and prints. At the same time, popularity of sporty styles continued, and comfortable pants shown in oversea collections were modified and accepted as slim and more sportive pants.

Another important result is that use of colors, materials and details are very limited in the street fashion. For example, while oversea collections presented trench coats in various colors in $02 \mathrm{~s} / \mathrm{s}$, only beige was frequently observed in the street fashion. Strings were applied only on pants $(03 \mathrm{~s} / \mathrm{s})$ and pleats in skirts(03-04 f/w), tiered skirts(05 s/s) and drapes in top $(05 \mathrm{~s} / \mathrm{s})$ in the street fashion, whereas strings, pleats, tiered, drapes were used in wide variety of items in oversea collections. Limited use of colors, details and materials in the street fashion may not be surprising since designers in oversea collections are to present creative designs with inspiring ideas, but for mass fashion only limited colors, materials, prints and details may be economically or technically feasible.

Solid colors were far more frequently worn in the street fashion even though floral prints, and stripes, oriental prints to less degree were popular during some spring and summer seasons, and there was lack of patterns and prints in the street fashion, particularly during fall and winter.

Motifs and patterns were smaller in Korea compared to when they were used in oversea collections

Table 2. Styles of partial acceptance

\begin{tabular}{|c|c|c|c|c|}
\hline & Style/Item & Fashion Show & SFDC & Examples \\
\hline $\begin{array}{l}02 \\
\mathrm{~s} / \mathrm{s}\end{array}$ & $\begin{array}{l}\text { Masculine \& feminine suit } \\
\text { Single trench coat } \\
\text { Girlish blouse } \\
\text { Flare \& Fluid skirt } \\
\text { Cropped pants } \\
\text { Denim }\end{array}$ & $\begin{array}{l}\text { Androgyny in details of suits } \\
\text { Below-knee length coats, various } \\
\text { colors } \\
\text { Flared sleeves with many details } \\
\text { Irregular hem-lined flare skirt } \\
\text { Knee-length, comfortable style } \\
\text { Bohemian style }\end{array}$ & $\begin{array}{l}\text { Feminine skirt, masculine pants } \\
\text { Knee-length, beige } \\
\text { Frill,white } \\
\text { Below-knee flare skirt, black } \\
\text { Sporty cropped pants } \\
\text { Feminine style }\end{array}$ & $\begin{array}{l}\begin{array}{l}\text { [Flare } \\
\text { \& fluid } \\
\text { skirt] }\end{array} \\
\text { (1) } 02 \mathrm{~s} / \mathrm{s} \mathrm{Fa}\end{array}$ \\
\hline $\begin{array}{l}03 \\
\mathrm{~s} / \mathrm{s}\end{array}$ & $\begin{array}{l}\text { Shirt variation } \\
\text { Sports essence } \\
\text { Sporty pants } \\
\text { Cropped pants } \\
\text { Micro mini } \\
\text { String }\end{array}$ & $\begin{array}{l}\text { Chiffon, mannish style } \\
\text { Loose \& fit silhouette } \\
\text { Satin, chiffon, loose design } \\
\text { Feminine cropped pants } \\
\text { Pants \& shirt } \\
\text { In all items }\end{array}$ & $\begin{array}{l}\text { Chiffon, oriental style } \\
\text { Training jumper \& pants, } \\
\text { side seam detail } \\
\text { Training pants, tape lines on side } \\
\text { seams } \\
\text { Sporty cropped pants } \\
\text { Denim skirt } \\
\text { Only in pants }\end{array}$ & (2) $03 \mathrm{~s} / \mathrm{s}$ Fasl \\
\hline $\begin{array}{l}04 \\
\mathrm{~s} / \mathrm{s}\end{array}$ & $\begin{array}{l}\text { Knee Length skirts } \\
\text { One-piece variation } \\
\text { Sports variation } \\
\text { Cropped top } \\
\text { Ruffles \& Tiers } \\
\text { Short pants } \\
\text { Colorful denim }\end{array}$ & $\begin{array}{l}\text { H-line, tight skirts } \\
\text { Prints, shiny materials } \\
\text { Loose top, short bottom } \\
\text { Outer wear, short length } \\
\text { In all items, feminine style } \\
\text { Variety of materials } \\
\text { Variety of colors and items }\end{array}$ & $\begin{array}{l}\text { White, flared skirts } \\
\text { Floral prints, stripes } \\
\text { Tight top, training jumper \& pants } \\
\text { Short t-shirts, layered } \\
\text { Only in skirts } \\
\text { Only in denim pants } \\
\text { Blue tone only }\end{array}$ & $\begin{array}{l}\text { [Cropped, } \\
\text { top] } \\
\text { (3) } 04 \mathrm{~s} / \mathrm{s} \text { Fashion Show p. } 91\end{array}$ \\
\hline $\begin{array}{l}05 \\
\mathrm{~s} / \mathrm{s}\end{array}$ & $\begin{array}{l}\text { Natural look } \\
\text { Blouson } \\
\text { Short pants } \\
\text { Pleats } \\
\text { Tiered } \\
\text { Drape } \\
\text { Botanical pattern } \\
\text { Cotton \& linen }\end{array}$ & $\begin{array}{l}\text { Natural \& elegant } \\
\text { Simple \& classic } \\
\text { Satin, variety of prints } \\
\text { In all items } \\
\text { Mainly in skirts, details } \\
\text { Jersey, chiffon, loose silhouette } \\
\text { Large, vibrant prints } \\
\text { White }\end{array}$ & $\begin{array}{l}\text { Vintage casual } \\
\text { Sporty } \\
\text { Blue denim } \\
\text { Only in skirts } \\
\text { Mainly in long skirts } \\
\text { Jersey tops } \\
\text { Small prints } \\
\text { Brown tone }\end{array}$ & $\begin{array}{l}\text { [Tiered] } \\
\text { (4) } 05 \mathrm{~s} / \mathrm{s} \text { Fashion Show p. } 46\end{array}$ \\
\hline
\end{tabular}


Table 2. Continued

\begin{tabular}{|c|c|c|c|c|}
\hline & Style/ltem & Show & SFDC & \\
\hline $\begin{array}{c}02-03 \\
f / w\end{array}$ & $\begin{array}{l}\text { Urban coats } \\
\text { Simple blouses } \\
\text { Neo basic } \\
\text { British checks } \\
\text { Short jacket } \\
\text { Feminine pleated skirts } \\
\text { Masculine tailored }\end{array}$ & $\begin{array}{l}\text { Belted style } \\
\text { Elegant, \& simple } \\
\text { Variety of items in simple design } \\
\text { Mix \& match of checks \& other } \\
\text { patterns } \\
\text { Single button, mono color } \\
\text { Loose, pleats in all items } \\
\text { Masculine designs in many items }\end{array}$ & $\begin{array}{l}\text { Fur-trimming, tight waist line } \\
\text { Shirtsblouses } \\
\text { Mono color, basic } \\
\text { Check skirts, narrow checks } \\
\\
\text { Simple denim jacket } \\
\text { Skirts with wide pleats } \\
\text { All-black coordination }\end{array}$ & $\begin{array}{c}\text { [Neo basic] } \\
\text { (1) } 02-03 \mathrm{f} / \mathrm{w} \text { Fashion } \\
\text { p. } 118\end{array}$ \\
\hline $\begin{array}{c}03-04 \\
f / w\end{array}$ & $\begin{array}{l}\text { Minimal coats } \\
\text { Modern skirt } \\
\text { Variety collar jacket } \\
\text { Slim pants } \\
\text { Lovely pleats } \\
\text { Check } \\
\text { Roomy pants }\end{array}$ & $\begin{array}{l}\text { Black gray, knee-length } \\
\text { Various styles } \\
\text { Various collars } \\
\text { Drastically reduced around ankle } \\
\text { Pleats details } \\
\text { Vivid wide checks } \\
\text { Full length, wider at the bottom }\end{array}$ & $\begin{array}{l}\text { Gray half-coats } \\
\text { Pleats skirt, gray } \\
\text { Various materials, sherpa } \\
\text { Tight denim pants. } \\
\text { Pleat skirts } \\
\text { British check skirts } \\
\text { Roomy pants }\end{array}$ & (2) 03-04 f/w Fashion Show p. 48 \\
\hline $\begin{array}{c}04-05 \\
\mathrm{f} / \mathrm{w}\end{array}$ & $\begin{array}{l}\text { Classic short jacket } \\
\text { Mid one piece } \\
\text { Blouson \& jacket } \\
\text { Cropped top } \\
\text { Feminine top } \\
\text { Sleeveless(vest) } \\
\text { High neck } \\
\text { Skirt variation } \\
\text { Pleats skirt } \\
\text { Animal pattern } \\
\text { Print variation } \\
\text { Cape \& blanket coat }\end{array}$ & $\begin{array}{l}\text { Minimal design, gray tone } \\
\text { Mono color } \\
\text { Mannish blouson, feminine jacket } \\
\text { Short jacket, shorter sleever } \\
\text { Chiffon, satin } \\
\text { Layering of vests } \\
\text { Mainly in jackets, various styles } \\
\text { Irregular hemlines } \\
\text { Feminine styles, various pleats } \\
\text { Tiger prints, \& zebra prints } \\
\text { Floral prints, stripes, geometric } \\
\text { patterns } \\
\text { Various materials, \& patterns }\end{array}$ & $\begin{array}{l}\text { Various colors, \& materials } \\
\text { Small prints } \\
\text { Denim jacket } \\
\text { Short jacket, long sleeve } \\
\text { Ruffles, prints } \\
\text { Sleeveless shirts or T-shirts } \\
\text { Turtleneck sweater } \\
\text { School girl look, pleats skirt. } \\
\text { School girl look } \\
\text { Limited use of tiger prints } \\
\text { Ethnic prints \& oriental print } \\
\\
\text { Knitted cape }\end{array}$ & $\begin{array}{l}\begin{array}{c}\text { Cropped } \\
\text { top] }\end{array} \\
\text { (3) 04-05 f/w Fashion Show } \\
\text { p. } 310\end{array}$ \\
\hline
\end{tabular}

as shown in the case of botanical patterns for $05 \mathrm{~s} / \mathrm{s}$ and checks for $02-03 \mathrm{f} / \mathrm{w}$. Likewise, length of skirts and coats seemed to stay in moderation in the street fashion, whereas oversea collections present wide variations(for example, 03-04 f/w).

Flared skirts with irregular hem lines were quite strong in the collections for $02 \mathrm{~s} / \mathrm{s}$, but ordinary flared skirts were accepted and its popularity continued till $04 \mathrm{~s} / \mathrm{s}$. As in the case of flared skirts, certain styles and items were observed in the street fashion over several seasons, while oversea collections presented different styles every season. This difference is not surprising since ordinary consumers continue to wear their outfits for several seasons.

\section{Styles of Low Acceptance}

Table 3 shows the styles and items which were shown in oversea collections but not in the street fashion indicating low acceptance by Korean con- sumers. There seem to be certain commonalities which may contribute to low acceptance. First of all, volume seems to hinder consumer acceptance in Korea. Voluminous styles or items were not well accepted as shown in the cases of voluminous skirt(02 s/s), oversized pants $(03 \mathrm{~s} / \mathrm{s})$, drape one-piece $(04 \mathrm{~s} / \mathrm{s})$, long \& maxi coat $(02-03 \mathrm{f} / \mathrm{w})$, roomy pants $(02-03 \mathrm{f} / \mathrm{w})$ and bulky knits(03-04 f/w). The result showing low acceptance of voluminous styles in Korean may be attributed to the differences in body sizes between Koreans and westerners.

While the oversea collections shows diverse details used in dresses, many of them were observed in the street fashion. For example, crochet lace, embroidery, zipper, craft work, patch work, and cut-outs were used in oversea collections, but they were not observed in the street fashion. Technical and economical feasibility of mass production for certain details seem to determine whether the details would be accepted or not. 
Table 3. Styles of low acceptance

\begin{tabular}{|c|c|c|c|}
\hline $02 \mathrm{~s} / \mathrm{s}$ & $03 \mathrm{~s} / \mathrm{s}$ & $04 \mathrm{~s} / \mathrm{s}$ & $05 \mathrm{~s} / \mathrm{s}$ \\
\hline $\begin{array}{c}\text { Romantic Bohemian } \\
\text { World ethnic feeling } \\
\text { Unfinished detail } \\
\text { Sporty blouson } \\
\text { Bohemian blouse } \\
\text { Voluminous skirt } \\
\text { Fringe, tape, lace-up } \\
\text { Craft work } \\
\text { Midriff top } \\
\text { Cute shorts } \\
\text { Wild pants } \\
\text { Lingerie-look }\end{array}$ & $\begin{array}{c}\text { Mannish jacket } \\
\text { Classic suit } \\
\text { Trench \& stand coat } \\
\text { Neo-futurism } \\
\text { Off shoulder } \\
\text { Layered vest } \\
\text { Oversized shirts } \\
\text { Salopette } \\
\text { Jump suit } \\
\text { Rider's jacket } \\
\text { Blouson } \\
\text { Belted trench coats } \\
\text { Zipper accent } \\
\text { Pop motif }\end{array}$ & $\begin{array}{l}\text { Set-up Suit } \\
\text { Vest } \\
\text { Cropped pants } \\
\text { Irregular hem line } \\
\text { Drape one-piece }\end{array}$ & $\begin{array}{c}\text { Set-up suit } \\
\text { Masculine Essence } \\
\text { Coat variation } \\
\text { Combinaison } \\
\text { Crochet lace } \\
\text { Embroidery } \\
\text { Animal print } \\
\text { Leather \& suede }\end{array}$ \\
\hline $02-03 \mathrm{f} / \mathrm{w}$ & $03-04 \mathrm{f} / \mathrm{w}$ & $04-05 \mathrm{f} / \mathrm{w}$ & \\
\hline $\begin{array}{l}\text { Masculine tailored } \\
\text { Lovely black one-piece } \\
\text { Winter folklore } \\
\text { Hot layered } \\
\text { Patch work/ applique } \\
\text { Long \& maxi coat } \\
\text { Vests } \\
\text { Cropped pants } \\
\text { Ethnic one-piece } \\
\text { Ethnic pattern } \\
\text { Sporty chic } \\
\text { knit robe } \\
\text { Roomy pants }\end{array}$ & $\begin{array}{c}\text { Masculine elegance } \\
\text { Belted coats } \\
\text { One-piece variations } \\
60 \text { 's space age } \\
\text { Rock chic } \\
\text { Casual coat } \\
\text { Cropped tops } \\
\text { Rider's jackets } \\
\text { Cropped pants } \\
\text { One-piece variations } \\
\text { Vests } \\
\text { Cut-out } \\
\text { Geometric pattern } \\
\text { Animal pattern } \\
\text { Hooded tops } \\
\text { Capes \& stoles }\end{array}$ & $\begin{array}{l}\text { Belted coat } \\
\text { Minimal coat } \\
\text { Retro look } \\
\text { Fur accent } \\
\text { Slim pants } \\
\text { Fur \& mouton } \\
\text { Bulky knit }\end{array}$ & \\
\hline
\end{tabular}

Certain items or styles seemed hard to be accepted in Korea. Combinaison was often presented in oversea collections, but never observed in the street fashion. Neo-futurism(03 s/s), 60's space age $(03-04 \mathrm{f} / \mathrm{w})$, rock chic(03-04 f/w), retro look(04-05 f/w) were not well accepted in Korea compared to feminine and sporty styles. These styles of low acceptance are associated with the spirit of the period 60 's and 70 's.

Acceptance of some styles showed time lag between oversea collections and the street fashion. For example, lingerie look was presented in oversea collections for $02 \mathrm{~s} / \mathrm{s}$, was not observed in the street fashion in $02 \mathrm{~s} / \mathrm{s}$, but appeared later in $03 \mathrm{~s} / \mathrm{s}$. Offshoulder items presented for $03 \mathrm{~s} / \mathrm{s}$, ethnic styles for $02 \mathrm{~s} / \mathrm{s}$ and $02-03 \mathrm{f} / \mathrm{w}$ were all accepted and shown in the street later. This time lag between presentation of oversea collections and acceptance in the street fashion seems to indicate time required for fashion diffusion in spite of short fashion cycles in contemporary world.

\section{Styles Unique in Korean Street Fashion}

In comparing oversea collections to the street fashion in Korea, there are certain styles or items which appeared only in Korean street fashion(Table 4). The uniqueness was often observed in specific accessories such as $\operatorname{cap}(02 \mathrm{~s} / \mathrm{s})$, scarf belt(04 s/s), leggings $(05 \mathrm{~s} / \mathrm{s})$, half-stockings $(02-03 \mathrm{f} / \mathrm{w})$, different styles of mufflers during fall and winter seasons, and boots (04-05 f/w), and clothing items such as bolero(03 s/ $\mathrm{s})$, duffle coat $(02-03 \mathrm{f} / \mathrm{w})$ and leather jacket $(02 \mathrm{~s} / \mathrm{s}$, 03-04 f/w). Popularity of these items, both accesso- 


\begin{tabular}{|c|c|c|c|}
\hline $\begin{array}{c}02 \mathrm{~s} / \mathrm{s} \\
\text { [Lingerie-look] } \\
\text { [World Ethnic feeing] }\end{array}$ & $\begin{array}{c}03 \mathrm{~s} / \mathrm{s} \\
\text { [Neo-futurism] } \\
\text { [Off shoulder] }\end{array}$ & $\begin{array}{c}\text { 04 s/s } \\
\text { [Drape one-piece] } \\
\text { [Irregular Hemline] }\end{array}$ & $\begin{array}{c}05 \mathrm{~s} / \mathrm{s} \\
\text { [Embroidery] } \\
\text { [Combinaison] }\end{array}$ \\
\hline & &
\end{tabular}

Fig. 2. Examples of low acceptance styles.

ries and clothing, was confined in one season, except leather jackets which were frequently observed in the street over several seasons beginning $02 \mathrm{~s} / \mathrm{s}$.

Military look was frequently observed in the street fashion in $03 \mathrm{~s} / \mathrm{s}$, even though it was not presented in oversea collections. In addition, layered look was very strong continuously during spring and summer seasons beginning $03 \mathrm{~s} / \mathrm{s}$. Several items, usually tops, were layered and the layered look seems to be an ingenuous way of wearing skinny tops, sleeveless tshirts, and vests avoiding overexposure. As layer look continued to be popular, leggings were frequently worn in $05 \mathrm{~s} / \mathrm{s}$.

Interestingly, there was eye-catching color scheme in each season in Korea particularly during spring and summer seasons. Blue $(03 \mathrm{~s} / \mathrm{s})$, vivid colors $(04 \mathrm{~s} /$ $\mathrm{s})$, psychedelic color(05 s/s) and purple(04-05 early fall) were observed in the street, and they were not associated with overall trend or popular styles. These eye catching colors may be mass produced and mass marketed as accent colors to spark consumer interests as new season begins.

While the designers in oversea collections present different styles every season, some styles or items were continuously worn and observed in the street fashion. Oriental style which was widely accepted in $03 \mathrm{~s} / \mathrm{s}$ continued to be observed in $04 \mathrm{~s} / \mathrm{s}$ even though the style was no longer shown in oversea collections.

Some cases confined in Korean street fashion were found in the timing of outfit rather than the style itself. Leather jackets were frequently observed in 02 $\mathrm{s} / \mathrm{s}$ which may be attributed to cold weather in March. Boots popular in 04-05 f/w were observed quite early in season and they were sometimes worn with summer outfits.

\section{Conclusions and Limitations}

This research dealt with consumer acceptance of fashion styles which were forecasted in oversea collections by leading designers and apparel firms. The study compared the street fashion data collected in Seoul to the styles presented in oversea collections held in Paris, Milan, London and New York from 02 $\mathrm{s} / \mathrm{s}$ to $05 \mathrm{~s} / \mathrm{s}$ seasons. The styles were categorized into four groups - styles of high acceptance, partial accep- 
Table 4. Styles unique in Korean street fashion

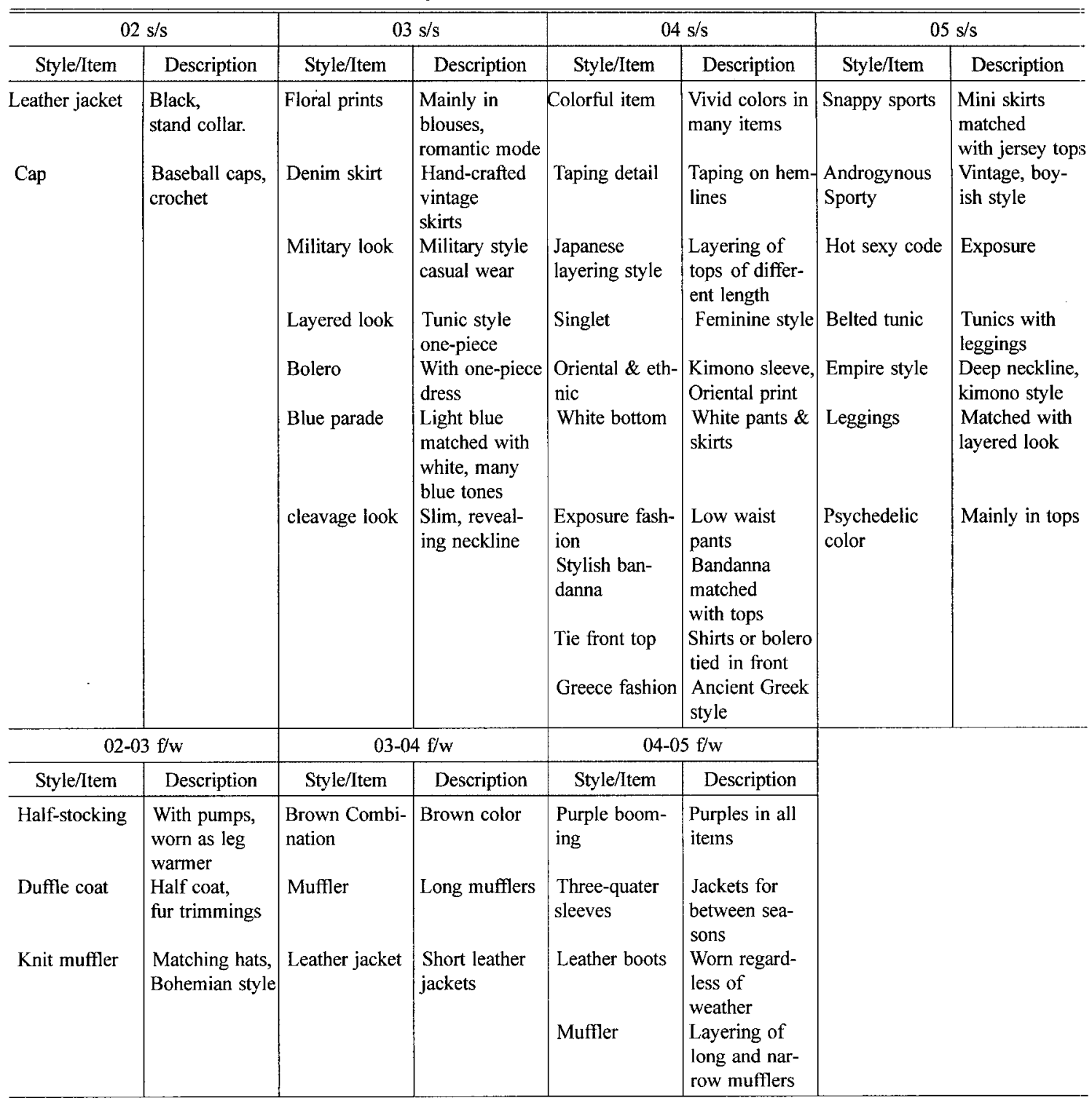

tance, and low acceptance and styles unique in Korean street fashion. The styles of high acceptance showed that overall trends presented in oversea collections were generally well accepted. During the period of this research, sporty style and feminine style were very strong in the street fashion, and all items or styles were accepted only when they were consistent with sporty or feminine styles or they were modified in a way consistent with sporty and femi- nine styles. Dominance of the limited styles found in this study is consistent with the result reported by Lee(2003). The result also seems to confirm that Korean society can be characterized by high collectivism as suggested by Hofstede and Hofstede(2005). In addition, the high acceptance of feminine styles suggests that confucius teachings emphasizing traditional differences in sex roles may still remain strong in Korea in spite of rapid industrialization and eco- 


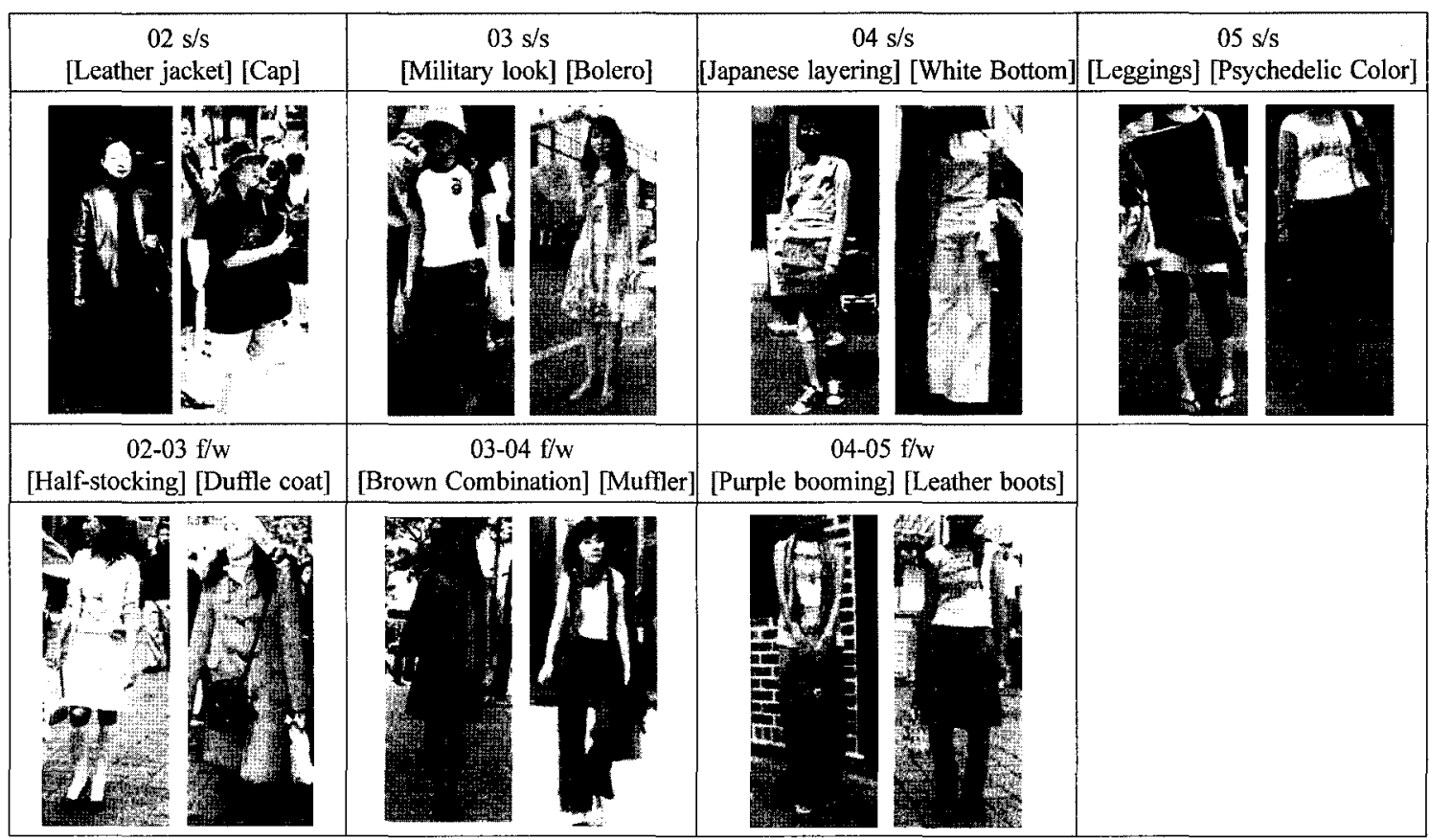

Fig. 3. Examples of styles unique in Korean street fashion.

nomic development(Kim, 1991). At the same time, continuous popularity of sporty styles may be attributed to the dynamic nature of Korean society including high mobility of its citizens particularly in Seoul. Contrasting characteristics of Korean society containing both eastern and western culture have been also noted by Hyun(2001).

Solid colors in comparison to prints, and floral and stripes in comparison to other patterns, and kneelength skirts compared to full-length skirts have been well accepted. High acceptance of limited colors and prints is consistent with dominance of limited styles in Korean street fashion as discussed above. And they may be also explained by high collectivism, and relatively conservative nature of Korean society. Only a limited materials, colors, patterns or details were accepted in the street fashion, while the oversea collections tend to present diverse techniques, materials and innovative applications of details. In addition, size of motifs in patterns, colors and silhouettes were much more moderate in the street fashion compared to oversea collections. These results of partial acceptance may be attributed to cultural characteristics of
Korean fashion as well as limitation in mass production.

Some commonalities were noted among the styles not accepted in the street fashion. Styles or items of large volume such as voluminous skirts, and oversized pants were not accepted in the street fashion. The styles which are associated with the spirits of 60 's or 70's were not well accepted either. Time lag of one year between oversea collections and the street fashion was noted for certain styles such as lingerie look, off-shoulder, and ethnic styles. Lingerie look and off-shoulder style are quite body-revealing compared to the styles accepted in the same season as the fashion collections. Thus acceptance of these styles may have taken time in relatively conservative Korean culture. It should be also pointed that time-lagged acceptance was limited indicating that in most cases acceptance of styles presented in oversea fashion collections would be determined in the corresponding seasons in Korea. And as expected, some styles were worn longer in the street fashion whereas styles in oversea collections changed every season. Most of the cases observed only in Korean street fashion 
involved accessories such as caps, leggings, and mufflers. In addition, it was notable that there is a color of season, particularly for spring and summer, that is marketed regardless of trends and accepted by consumers.

In summary, the results of this study suggest that while the overall trends of oversea fashion collections were generally well accepted in Korea, acceptance of individual styles seemed to vary depending whether they are consistent with collective and somewhat conservative culture in Korea. In addition, it should be pointed that differences between street fashion and oversea fashion collection data could be attributed to the differences between mass production and production of high fashion.

This study examined the consumer acceptance of fashion forecast by comparing the street fashion and oversea collections. Street fashion data, even though highly valuable in investigating what is actually accepted by consumers, are not inclusive of all clothing categories such as formal wears. Therefore, it may be necessary to explore consumer acceptance in different categories, particularly high end categories. In addition, the data used in this study were collected only in limited areas in Seoul. It should be pointed that generalization of the results may be limited due to limitation of secondary data used in this research. Research methods were also limited into content analysis because the study was based on qualitative as well as secondary data. Future research is needed to expand the scope of consumer acceptance study and broaden our understanding on the characteristic of Korean society related to consumer acceptance of fashion.

\section{References}

Behling, D. (1992). Three and a half decades of fashion adoption research: What have we learned? Clothing and Textile Research Journal, I0(2), 34-41.

Brannon, E. (2005). Fashion forecasting. NY: Berg.

Burns, L. \& Bryant, N. (1997). The business of fashion. NY: Fairchild Publications.

Cameron, D. (2000). Off -the-rack identities: Japanese street fashion magazines and the commodification of style. Japanese Studies, 20(2), 179-187.

Forsythe, S., Butler, S., \& Kim, M. (1991). Fashion adoption: Theory and pragmatics. Clothing and Textile Research Journal, 9(4), 8-15.

Ha, J. (2005). A study on the aesthetic values related to the morality expressed in recent Korean street fashion. Journal of the Korean Society of Clothing and Textiles, 29(2), 379-390.

Hofstede, G. \& Hofstede, G. (2005). Culture and organizations: Software of the mind. New York: McGraw-Hill.

Hyun, K. (2001). Sociocultural change and traditional values: Confucian values among Koreans and Korean Americans. International Journal of Intercultural Relations; 25(2), 203-229.

Kim, C. (2003). Men's street fashion in world fashion-leading cities: Classification and style analysis. Journal of the Korean Society of Clothing and Textiles, 27(3/4), 298-309.

Kim, J. (1991). The Koreans: Their mind and behavior. Seoul: Korea Research Foundation, Kyobo Book Center.

Kim, J. (2001). An analysis of consumers' acceptance of the recent fashion trends for domestic women's wear market. Master's thesis, Yonsei University, Seoul.

Lee, I. (2003). A study on the relativity between fashion trend and consumer acceptance. Journal of Korean Home Economics Association, 41(10), 185-198.

Lee, W. (2001). Fashion trend forecasting information acceptance of mass fashion. Doctoral dissertation, Kyung Hee University, Seoul.

Park, S. (2000). Comparative study on fashion trends between Korean and foreign fashion collections in the $1990 \mathrm{~s}$. Master's thesis, Seoul National University, Seoul.

Shin, H. (2001). An analysis of consumer's acceptance and needs for the recent fashion trends in domestic women's wear market. Master's thesis, Yonsei University, Seoul. 


\section{요 약}

빠른 유행변화와 긴 제조과정으로 인하여 패션업계에서 유행예측은 매우 중요한 과업이며, 성공의 열 쇠가 된다. 따라서 예측된 스타일이 소비자들에게 수용되어 유행되는 과정은 학문적으로나 산업적으로 매우 중요한 주제이다. 이 연구는 해외 콜렉션에서 예측된 유행스타일들이 한국시장에서 어떻게 수용되 는지를 알아보고자 여성복 해외 콜렉션 자료와 서울의 스트리트패션 자료를 $02 \mathrm{~s} / \mathrm{s}$ 시즌부터 $05 \mathrm{~s} / \mathrm{s}$ 시즌 까지 7 시즌에 걸쳐 비교하였다. 해외 콜렉션 자료는 전문 패션잡지인 Fashion Show에서 수집하였으며, 스트리트 패션자료는 서울패션디자인센터의 자료를 사용하였다. 그 결과 우리나라는 해외 콜렉션에서 나 타난 전반적인 트렌드를 잘 수용하고 있으며 특히 이 기간 동안은 스포티 스타일과 페미닌 스타일이 크게 유행하였던 것으로 나타났다. 그러나 해외 콜렉션에서 나타난 스타일이 그대로 수용되기 보다는 변형되 거나, 일부만이 수용되는 경우가 더 많았으며 이것은 한국사회의 특성과 대량생산에 기인한 것으로 사료 된다. 또한 해외 콜렉션에서 제시된 스타일들 중 한국에서는 거의 수용되지 않은 경우도 있었으며, 한편 한국에서만 나타난 스타일과 아이템들도 있었다. 이 연구는 해외 콜렉션 자료를 주 정보원으로 사용하는 국내 의류업체돌의 상품기획에 좋은 가이드라인을 제공하고 있으며, 또한 한국 패션시장의 특성을 이해 하는데 도움이 되는 실증적인 연구로 의의가 있다. 